\title{
Adaptation and validation to Portuguese of the Reasons for Higher Education Dropout Scale
}

Adaptação e validação para português da Escala de Motivos de Intençáo de Abandono do Ensino Superior

Adaptación y validación al portugués de la Escala de Motivos de Intención de Abandono de la Enseñanza Superior

Manuela Ferreira*iD; João Duarte**iD; José Luís Abrantes***iD; Lídia Cabral****iD; Raquel Guiné*****iD;

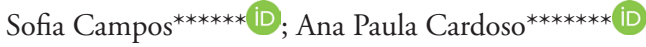

\section{Abstract}

Background: School dropout is a problem education systems struggle with, which disputes the quality of the educational institution and the education system itself.

Objectives: To adapt and validate the psychometric qualities of the Reasons for Higher Education Dropout Scale for Portuguese higher education students.

Methodology: Quantitative, transversal, descriptive, and correlational study. A sociodemographic characterization questionnaire and the Reasons for Higher Education Dropout Scale were applied to a sample of 891 students, mostly female (68.2\%), with a mean age of 19.68 years. Exploratory and confirmatory factor analysis was used.

Results: The scale, consisted of 30 items, is organized into 4 dimensions: Organizational; Life management; Professional; and Relational. It presents an explained variance of $46.5 \%$ and a Cronbach's alpha of 0.959 .

Conclusion: The results support the psychometric adequacy of the scale for the Portuguese population and indicate that it can be used in future studies in this area and allow the implementation of measures to prevent dropout.

Keywords: student dropouts; education, higher; validation studies; reliability and validity

\section{Resumo}

Enquadramento: $\mathrm{O}$ abandono escolar é um problema com que os sistemas educacionais se debatem, colocando em causa a qualidade da instituição escolar e do próprio sistema de ensino.

Objetivos: Adaptar e avaliar as qualidades psicométricas da Escala de Motivos de Intençáo de Abandono do Ensino Superior para os estudantes do ensino superior português. Metodologia: Estudo quantitativo, transversal, descritivo e correlacional. Foi aplicado um questionário de caracterização sociodemográfica e a Escala de Motivos de Intenção de Abandono do Ensino Superior a uma amostra de 891 estudantes, maioritariamente feminina $(68,2 \%)$, com uma idade média de 19,68 anos. Recorreu-se à análise fatorial exploratória e confirmatória.

Resultados: A escala composta por 30 itens, organizados em 4 dimensões: Organizacional; Gestão de vida; Profissional e Relacional. Apresenta uma variância explicada de 46,5\%, e um alfa de Cronbach de 0,959.

Conclusão: Os resultados apoiam a adequação psicométrica da escala para a populaçáo portuguesa, indicando que poderá ser utilizada em ensaios futuros neste âmbito e permitir a implementação de medidas que o contrariem.

Palavras-chave: evasão escolar; ensino superior; estudos de validação; confiabilidade e validade

*Ph.D., Coordinating Professor, Polvtechnic Institute of Viseu, Health School, CI\&DETS 3500-843, Viseu, Portugal [mmcferreira@gmail.com]. D https://orcid.org/0000-0002 8452-2222. Contribution to the article: project conception; creation and implementation of the formative intervention program; data analysis and interpretation; article writing and final approval of the submitted version. Address for correspondence: Rua D. João Crisóstomo Gomes de Almeida, n. ${ }^{\circ} 102,3500-843$, Viseu, Portugal.

**Ph.D., Coordinating Professor, Polvtechnic Institute of Viseu, Health School, CI\&DETS, 3500-843, Viseu, Portugal [duarte.johnny@gmail.com].D https://orcid.org/0000-00017082-8012. Contribution to the article: data analysis and interpretation; article writing and final approval of the submitted version

***:Ph.D., Coordinating Professor, Polytechnic Institute of Viseu, School of Technology and Management of Viseu, CI\&DETS, 3504-510, Viseu, Portugal [jlabrantes1966@gmail.com] (D) https://orcid.org/0000-0003-0565-7207. Contribution to the article: data analysis and interpretation, and article writing.

****.Ph.D., Coordinating Professor, Polytechnic Institute of Viseu, Health School, CI\&DETS, 3500-843, Viseu, Portugal [lcabral@essvipv.pt]. (10 https://orcid.org/0000-0001-7306-5049. Contribution to the article: project conception; creation and implementation of the formative intervention program; and article writing

35: Ph.D. Coordinating Professor, Polytechnic Institute of Viseu, Agrarian School, CI\&DETS

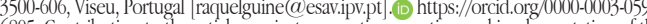
formative intervention program; and article writing

3500-8 3500-843, 15 , Port 位 of the formative intervention program; and article writing.

3500-155 Viseu, Coordinating Professor, Polytechnic Institute of Viseu, School of Education, 3500-155, Viseu, Portugal [a.p.cardoso62@gmail.com]. (1) https://orcid.org/0000-0001-5062formative intervention program; and article writing.

\section{Resumen}

Marco contextual: El abandono escolar es un problema al que los sistemas educativos se enfrentan, y que pone en causa la calidad de la institución escolar y del propio sistema de enseñanza.

Objetivos: Adaptar y evaluar las cualidades psicométricas de la Escala de Motivos de Intención de Abandono de la Enseñanza Superior para los estudiantes de la enseñanza superior portuguesa.

Metodología: Estudio cuantitativo, transversal, descriptivo y correlacional. Se aplicó un cuestionario de caracterización sociodemográfica y la Escala de Motivos de Intención de Abandono de la Enseńanza Superior a una muestra de 891 estudiantes, mayoritariamente femenina $(68,2 \%)$, con una edad media de 19,68 años. Se recurrió al análisis factorial exploratorio y confirmatorio.

Resultados: La escala estuvo compuesta por 30 ítems, organizados en 4 dimensiones: Organizativa; Gestión de la vida; Profesional y Relacional. Presenta una varianza explicada del $46,5 \%$ y un alfa de Cronbach de $0,959$.

Conclusión: Los resultados apoyan la adecuación psicométrica de la escala para la población portuguesa, lo que indica que se podrá utilizar en ensayos futuros en este ámbito y permitir la implementación de medidas que lo contraríen.

Palabras clave: abandono escolar; educación superior; estudios de validación; confiabilidad y validez 


\section{Introduction}

Higher education dropout is becoming an increasingly evident political and social issue and has also been discussed within the scientific community and institutions (Ferreira \& Fernandes, 2015). The access of a varied audience to higher education has brought new challenges and new responsibilities to higher education institutions, particularly that of ensuring that all students have equal opportunities for academic permanence and success. The reasons for dropout are very diverse. Professional and life management reasons, that is, sometimes it is related to the high demand in the labor market. There are also social, economic, and personal reasons, not forgetting when the reason is the students' poor relationship with their educational institution. The use of reliable instruments is extremely important to confirm the need for intervention within the context of academic success promotion. Therefore, the objective of this study is to adapt and evaluate the psychometric qualities of the Reasons for Higher Education Dropout Scale (Ambiel, 2015) for Portuguese higher education students. Following the procedures recommended in the scientific literature, the aim is to provide to the community a reliable instrument, capable of assessing what it is meant to assess.

\section{Background}

In recent years, promoting higher education success has been a primary objective of public policies and initiatives of higher education institutions. Nevertheless, academic failure and dropout must still be considered worrying problems, both by the students affected by them and the higher education system and the Portuguese society as a whole. There is a current set of specific circumstances, namely the increasing importance of higher qualifications to the current economic panorama, which is increasingly supported on knowledge and innovation (Costa $\&$ Lopes, 2008).

The Ministry of Science, Technology, and Higher Education issued in 1999 the Order no. 6659/99 of 5 April (Despacho n. ${ }^{\circ} 6659 / 99$ de 5 de abril, 1999), underlining the relevance of this academic dropout problem and requesting from higher education institutions the production of studies to define the causes of higher education failure/ dropout and to support the implementation of preventive measures. In 2013, the Portuguese government issued the Resolution of the Republic Assembly no. 60/2013 (Resolução da Assembleia da República n. ${ }^{\circ}$ 60/2013 de 18 de abril, 2013), requesting an annual report on higher education dropout and, in 2014, the document "Higher Education Strategic Guidelines" (Direção-Geral do Ensino Superior, 2014) where action measures are defined, namely the creation of the Retomar Program, directed at increasing school success and reducing dropout rates.

The first college year is, as described by Albuquerque (2008), a problem for many students. Academic failure, dropouts, and the apparent lack of motivation of many students become concerning factors for higher education institutions. In this respect, the author developed a study which aimed to "understand how students who enroll in a course, which was not their first choice, adapt to higher education and why they choose not to abandon it" (Albuquerque, 2008, p. 19).

Results indicated that, through the practical academic activities undertaken during the course, students began to understand the profession, the type of population they would work with, and the type of work they would develop. It was concluded that the involvement of students in the course and the pedagogical relationship are the factors that most influence the decisions of the permanence of these students. (Albuquerque, 2008, p. 19)

On the other hand, by analyzing the path of all students enrolled in the $1^{\text {st }}$ year, for the first time, in 2011/2012, Baptista (2015) sought to define their situation after one year, more specifically in the academic year of 2012/2013. He concluded that in undergraduate courses of public education, the panorama is similar to university and polytechnic education, whose dropout rate is about $12 \%$ after 1 year.

Thus, it is important to understand the factors that could influence academic success in higher education, including emotional skills, the quality of academic life, and other sociodemographic variables.

The factors that influence the academic profile of students, particularly in higher education, can be analyzed from a multidimensional perspective, comprising the

inherent dimension of the student (education path, socio-economic data, personal contact information, and psychological factors), the pedagogical dimension (relationship between teachers and students and organization of the curriculum), the institutional dimension (conditions of attendance, degree of integration, services and equipment) and the external environmental dimension (university-related, cultural, and geographical). (Sequeira, 2013, p. 14) 


\section{Research questions}

What are the explanatory dimensions of the Reasons for Higher Education Dropout Scale? Is the hypothesized 4-factor model validated by the confirmatory factor analysis?

\section{Methodology}

For the evaluation and refinement of measurement instruments, it is common practice to use statistical procedures, including reliability studies, such as the study of the internal consistency of items, and validity studies, more specifically the exploratory factorial analysis (EFA) and confirmatory factorial analysis. The aim is to determine the number and nature of the latent variables (factors) that best represent a set of observed variables (manifest variables). To this end, a psychometric and methodological research was outlined because, in addition to development, validation, and assessment of research tools and methods, this study seeks to define useful values to support the selection of valid and reliable instruments in future researches and, thus, to ensure the quality of results.

\section{Participants}

The sample for this study is non-probabilistic by convenience consisting of $8911^{\text {st }}$-year higher education students, of whom $3.6 \%$ study in the area of health, $20.9 \%$ in education, $24.7 \%$ in agrarian sciences, and $40.8 \%$ in the area of technology. The participants had a minimum age of 17 years and a maximum of $40(M=19.68$ years \pm 2.34 years). The male representatives were $31.8 \%$, and the female $68.2 \%$.

\section{Instrument}

The school dropout scale was developed by Ambiel (2015) and is a standardized instrument, in the form of an inventory, which assesses the potential reasons for enrolled students to leave their courses before completion.

In its original form, this scale is composed of 53 items related to the reasons that influence the decision of a student to drop out of a university degree. It has a five-point Likert-type answer key, ranging between 1 - very weak and 5 - very strong. The instrument is subdivided into seven factors: Institutional reasons (Factor 1); Personal reasons (Factor 2); Reasons related to lack of support (Factor 3); Professional Reasons (Factor 4); Reasons related to academic performance (Factor 5); Interpersonal Reasons (Factor 6), and Reasons related with autonomy (Factor 7). This study performed the linguistic adaptation and validation for European Portuguese of the scale.

\section{Adaptation of the scale into European Por- tuguese}

Although developed and presented in Portuguese, the scale had Brazilian Portuguese terminology, so the content of the items was validated, using two procedures: expert analysis and semantic analysis.

Five experts in the area of education were consulted and provided their contribution. Then, their opinions were subjected to a descriptive analysis, checking the rate of agreement for each item. A criterion was defined as to incorporate items with more than $75 \%$ agreement among experts. Items with a lower percentage, when suggested, suffered alterations. As a result, five items were modified. Finally, for the semantic analysis, that is, to analyze the understanding of the items, a pre-test was conducted with 25 students. All modifications and suggestions were incorporated in the final version of the scale.

\section{Procedures for data analysis}

A questionnaire on sociodemographic characteristics and the Reasons for Higher Education Dropout Scale (Ambiel, 2015) were applied. The purpose of the study was to determine and test the factorial structure of the Reasons for Higher Education Dropout Scale for Portuguese university students. Thus, the homogeneity between items, that is, the internal consistency, was assessed by means of calculating the Cronbach's alpha coefficient $(\alpha)$ both for the items and the total scale. As for the validity studies, the exploratory factor analysis used the principal component method and the orthogonal varimax rotation procedure. For factor retention, the eigenvalues greater than 1 and the scree plot were taken into account. The criterion for items saturation were values equal to or higher than 0.20 (Marôco, 2014).

For the confirmatory factor analysis, the Analysis of Moment Structures (AMOS 24) software was used. Considering the covariance matrix, the Maximum Likelihood Estimation (MLE) algorithm was adopted for the estimation of parameters. The statistical procedures for data analysis were: (i) assessment of item sensitivity by skewness $(S k)$ and kurtosis $(K u)$ whose reference values are $\leq 3$ and $\leq 7$, respectively; (ii) construct validation based on a factor, convergent, and discriminant analysis (Marôco, 2014).

The factor validity analysis was based on the quality of the global fit of the factorial model and the local fit quality.

The global fit quality was assessed by means 
of the goodness of fit global indexes, as listed below with the following reference values: ratio of the $x^{2}$ statistic and degrees of freedom $\left(x^{2}\right)$ df), comparative fit index (CFI), goodness of fit index (GFI), $\geq 0.90$ values; root mean square error of approximation (RMSEA), root mean square residual (RMR), and standardized root mean square residual (SRMR), considering values below 0.08 appropriate (Marôco, 2014).

The local quality fit was assessed by factor loadings $(\lambda)$ and the reliability of individual items $(\delta)$. The reference values are a factorial saturation higher than 0.50 and individual reliability above 0.25 , respectively (Marôco, 2014).

The model fit used the modification indexes (above 11; $<<0.001$ ) produced by AMOS and based on theoretical considerations.

The composite reliability (CR) was assessed with the standardized Cronbach's alpha for each of the factors. Consistency is considered to be appropriate when the alpha value is greater than 0.7. Convergent validity estimated by the average variance extracted (AVE) showed that values above 0.50 indicate a good convergent validity (Marôco, 2014).

The discriminant factor validity was assessed by comparing the AVE for each factor with the squared Pearson correlation. This analysis showed that there is discriminant validity when the squared correlation between factors is lower than the AVE, for each factor.

\section{Ethical procedures}

All participants in the study received the necessary information and were asked to sign the informed consent form. Their anonymity and confidentiality of data were assured and their autonomy respected.

They were also informed that their participation was entirely free; they could withdraw from the study at any time; this participation did not imply any gains or benefits nor incur in any losses or harm. As for the ethics committee approval, the opinion delivered by the Viseu Higher School of Health (Ref. 08/2017) was favorable.

\section{Results}

The psychometric study began with determining the statistics for each of the items and later with the internal consistency analysis.

The statistics showed that the average indexes and their standard deviations have a well-centered distribution, all of them placed below the middle point. Regarding the correlation coefficients, it was found that almost all items show correlations above 0.20 (reference value; Pestana \& Gageiro,
2014), excepting the first item, which presents a slightly lower value. The analysis of the Cronbach alpha coefficients per item reveals that all items are equal to or higher than 0.958 , the global alpha being 0.959 .

After determining the internal consistency, the next step was conducting the validity studies using the scale's exploratory factor analysis. The adequacy of the factor analysis was assessed using the Kaiser-Meyer-Olkin (KMO) test, a statistical procedure that measures the quality of correlations between variables and that allows concluding whether it is possible to carry on with the factor analysis. Considering that the reference values are between 0.5 and 1 , this study obtained a $\mathrm{KMO}=0.958$, which can be classified as very adequate. The Bartlett's sphericity test, based on the chi-squared statistical distribution, was also carried out to test if there was no correlation between the variables. The result obtained $\left(x^{2}=\right.$ 25118,096; $p=0.000$ ) allows stating that the correlation matrix is not an identity matrix and, therefore, there is some correlation between the variables, expected to be included in the analysis. The exploratory factor analysis was, then, carried out on the 53 items, using the principal component method with orthogonal varimax rotation and latent roots higher than 1 (Marôco, 2014). The initial solution allowed selecting eight factors that explained, in total, $58.12 \%$ of the variability. However, the scree plot sustains the retention of four factors, according to the inflection point of the curve. Successive factor analyzes were made because of the elimination of items by saturation below 0.40 ou saturation in two or more factors with differences below the recommended value (0.15). The final solution, limited to four factors, allowed selecting 30 items distributed between the four factors which, together, explain $2 \%$ of the total variance.

Factor 1 was named Organizational Dimension and consisted of 8 items $(35,37,43,45,46$, 48,50 , and 51 ), which explains $14.53 \%$, after rotation. Factor 2 contains items 11, 18, 19, 21, 22, 49, and 52, and was named Life Management Dimension and explained $11.58 \%$. Factor 3, Professional Dimension, is composed of 8 items $(5,14,20,23,26,31,34$, and 36) and explains $11.43 \%$. Factor 4 was named Relational Dimension, whose construct includes items $(12,15,27,28,29,39$, and 41), and shows an explained variance of $10.84 \%$.

The 4-factor solution of this scale was tested using confirmatory factor analysis. Details relating to the multicollinearity and univariate and multivariate values that might influence the factorial analysis, among others, were analyzed. It was observed that the trajectories of the items with 
their corresponding factors are statistically significant, showing high factor loadings $(\lambda=0.50)$ and reliability higher than 0.25 . Exceptions were item 33 of factor 1, item 6 of factor 3, and item 2 of factor 4 , which were eliminated in a later analysis. The initial model was refined based on the modification indexes proposed by AMOS, which correlated some errors, and items with saturations below 0.50 were eliminated. The results of this procedure showed that the global fit was very adequate for the global fit indexes: $\chi^{2} / \mathrm{gl}=$ 4.494; $\mathrm{RMSEA}=0.063 ; \mathrm{RMR}=0.074 ; \mathrm{SRMR}$ $=0.057$; GFI $=0.878$; and $\mathrm{CFI}=0.887$, al though slightly lower than those recommended by Marôco (2014).

Accordingly, it was found that in factor 1 items $44,47,38,42,53,40$ and 33 were eliminated, in factor 2 items 1, 17 and 24, in factor 3 items $3,25,16,32,30$, and 6 , and in factor 4 items $10,7,4,2,8$, and 9 .

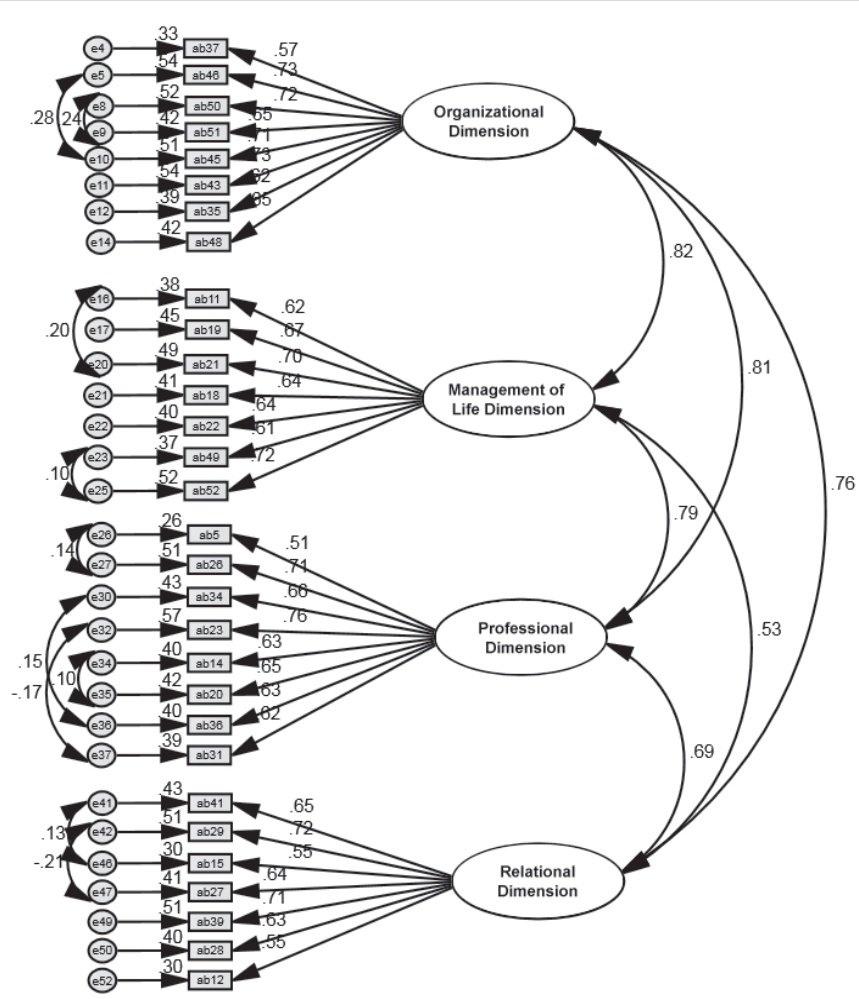

Figure 1. Model with modification indexes

Table 1 presents the global goodness of fit indexes. It should be noted that poor indexes exist only in the initial model, but after refining the model, they became adequate, except GFI and CFI, which improved but still have indexes slightly lower than the reference values.

Table 1

\section{Global Fit Indexes}

\begin{tabular}{lcccccc}
\hline Model & $\boldsymbol{x}^{2 /} \mathbf{g l}$ & GFI & CFI & RMSEA & RMR & SRMR \\
\hline Initial model (Figure 1) & 5.229 & 0.744 & 0.772 & 0.069 & 0.091 & 0.071 \\
\hline Model with modification indexes & 4.494 & 0.878 & 0.887 & 0.063 & 0.074 & 0.057 \\
\hline $2^{\text {nd }}$ model & 4.643 & 0.870 & 0.881 & 0.064 & 0.075 & 0.058 \\
\hline
\end{tabular}

Note. $x^{2 /} \mathrm{gl}=$ Ratio of the $x^{2}$ statistic and degrees of freedom; GFI = Goodness of Fit Index; CFI = Comparative Fit Index; RMSEA = Root Mean Square Error of Approximation; RMR = Root mean square residual; SRMR = Standardized root mean square residual. 
$\mathrm{CR}$ is, in all the factors, higher than the reference value (0.70), but AVE indicates that all factors have a value lower than the recommended $(0.50)$, concluding that there is a divergent validity in all factors.

Furthermore, the stratified coefficient is high (0.957) and presents an AVE of 0.431. In this sense, the instrument seems to be adequate for this sample, so it may be a valuable resource for the study of the intention of school dropout.

The next step was to carry out the study of the internal consistency by subscale (Table 2). Factor 1 (Organizational Dimension) shows, considering the mean values, homogeneity in the answers to the various items because the score obtained varies between $2.30 \pm 1.220$ in item 37 and $2.65 \pm 1.051$ in item 48. The Cronbach alpha coefficients per item show, if the item is eliminated, an internal consistency that varies between good and reasonable, the smallest value being that of item 46 with $\alpha=0.849$ and the greatest value $\alpha=0.867$ in item 37 .

Regarding Factor 2 (Life Management Dimension), the mean results reveal a homogeneity in the answers to the various items, because the score achieved ranges between $2.41 \pm 1.104$ in item 21 and $3.06 \pm 1.200$ in item 19. The Cronbach alpha coefficients show an internal consistency that varies between good and reasonable, the smallest value being $\alpha=0.815$, corresponding to item 21 , and the greatest value $\alpha=0.828$, corresponding to item 49 .

When analyzing the results of Factor 3 (Professional Dimension), it is noted that the mean indexes range between $2.51 \pm 1.014$ in item 31 and $2.83 \pm 1.162$ in item 5. The Cronbach alpha coefficients point out to a questionable internal consistency, as the smallest value is $\alpha$ $=0.826$, in item 26, and the largest $\alpha=0.850$, in item 5 .

As regards Factor 4 (Relational Dimension), the mean indexes range between $1.87 \pm 1.037$ in item 15 and $2.23 \pm 1.163$ in item 12 . The Cronbach alpha coefficients indicate an internal consistency between reasonable and questionable, the smallest value being $\alpha=0.788$, corresponding to item 41 , and the highest value $\alpha=0.814$, corresponding to item 12 .

Table 2

Internal Consistency by Subscale Statistics of the Higher Education Dropout Scale

\begin{tabular}{|c|c|c|c|c|c|c|}
\hline Items & & Mean & $S D$ & $\begin{array}{l}\text { total } r l \\
\text { item }\end{array}$ & $r^{2}$ & $\begin{array}{l}\alpha \text { without } \\
\text { item }\end{array}$ \\
\hline & Organizational Dimension & & & & & \\
\hline 35 & Teachers' teaching methods. & 2.65 & 1.102 & 0.573 & 0.338 & 0.864 \\
\hline 37 & No Internet available on campus. & 2.30 & 1.220 & 0.552 & 0.318 & 0.867 \\
\hline 43 & $\begin{array}{l}\text { No help from colleagues when I } \\
\text { struggle with learning something. }\end{array}$ & 2.31 & 1.042 & 0.666 & 0.451 & 0.854 \\
\hline 45 & $\begin{array}{l}\text { No time to participate in inter- } \\
\text { nships. }\end{array}$ & 2.49 & 1.095 & 0.664 & 0.502 & 0.854 \\
\hline 46 & $\begin{array}{l}\text { No pedagogical follow-up program } \\
\text { provided by the institution }\end{array}$ & 2.36 & 1.076 & 0.706 & 0.546 & 0.849 \\
\hline 48 & Below average grades & 2.65 & 1.051 & 0.574 & 0.338 & 0.863 \\
\hline 50 & $\begin{array}{l}\text { Lack of assistance in the coordina- } \\
\text { tion of the course. }\end{array}$ & 2.50 & 1.087 & 0.694 & 0.513 & 0.851 \\
\hline \multirow[t]{2}{*}{51} & $\begin{array}{l}\text { No exchange opportunities offered } \\
\text { by the institution. }\end{array}$ & 2.31 & 1.051 & 0.629 & 0.430 & 0.858 \\
\hline & Management of Life Dimension & & & & & \\
\hline 11 & Working during school hours. & 2.57 & 1.235 & 0.605 & 0.391 & 0.820 \\
\hline 18 & $\begin{array}{l}\text { Attending school/polytechnics by } \\
\text { family imposition. }\end{array}$ & 2.67 & 1.451 & 0.580 & 0.347 & 0.826 \\
\hline 19 & Household expenses increased. & 3.06 & 1.200 & 0.618 & 0.388 & 0.818 \\
\hline
\end{tabular}




\begin{tabular}{|c|c|c|c|c|c|c|}
\hline 21 & $\begin{array}{l}\text { Having to stop working to have } \\
\text { time for internships. }\end{array}$ & 2.41 & 1.104 & 0.647 & 0.439 & 0.815 \\
\hline 22 & A case of severe illness in the family. & 3.04 & 1.292 & 0.582 & 0.347 & 0.824 \\
\hline 49 & $\begin{array}{l}\text { Need to buy a property (house, } \\
\text { apartment...). }\end{array}$ & 2.69 & 1.298 & 0.558 & 0.330 & 0.828 \\
\hline \multirow[t]{2}{*}{52} & $\begin{array}{l}\text { Assuming new professional respon- } \\
\text { sibilities that make studies' conti- } \\
\text { nuation impossible. }\end{array}$ & 2.75 & 1.090 & 0.627 & 0.403 & 0.818 \\
\hline & Professional Dimension & & & & & \\
\hline 5 & $\begin{array}{l}\text { Having doubts regarding my career } \\
\text { choice. }\end{array}$ & 2.83 & 1.162 & 0.482 & 0.262 & 0.850 \\
\hline 14 & $\begin{array}{l}\text { Likely to have a low professional } \\
\text { recognition in the long term. }\end{array}$ & 2.74 & 1.109 & 0.588 & 0.355 & 0.836 \\
\hline 20 & Very limited labor market & 2.69 & 1.070 & 0.609 & 0.386 & 0.834 \\
\hline 23 & $\begin{array}{l}\text { Realizing that professional activity } \\
\text { will not be as enjoyable as imagined. }\end{array}$ & 2.76 & 1.118 & 0.664 & 0.452 & 0.827 \\
\hline 26 & $\begin{array}{l}\text { Realizing that the course will not } \\
\text { help to get a good job in the future. }\end{array}$ & 2.71 & 1.077 & 0.673 & 0.462 & 0.826 \\
\hline 31 & $\begin{array}{l}\text { Having a low performance in some } \\
\text { classes. }\end{array}$ & 2.51 & 1.014 & 0.518 & 0.281 & 0.844 \\
\hline 34 & $\begin{array}{l}\text { Career may not be as I thought it } \\
\text { would be. }\end{array}$ & 2.58 & 1.030 & 0.635 & 0.417 & 0.831 \\
\hline \multirow[t]{2}{*}{36} & Very low.professional wages. & 2.57 & 1.058 & 0.591 & 0.370 & 0.836 \\
\hline & Relational Dimension & & & & & \\
\hline 12 & $\begin{array}{l}\text { No friends at school/polytechnic } \\
\text { institute. }\end{array}$ & 2.23 & 1.163 & 0.478 & 0.235 & 0.814 \\
\hline 15 & Need to live in student residences. & 1.87 & 1.037 & 0.522 & 0.290 & 0.805 \\
\hline 27 & $\begin{array}{l}\text { Living far from school/polytechnic } \\
\text { institute. }\end{array}$ & 2.13 & 1.113 & 0.568 & 0.347 & 0.797 \\
\hline 28 & Having failed a class. & 2.05 & 1.069 & 0.540 & 0.336 & 0.802 \\
\hline 29 & $\begin{array}{l}\text { Realizing that people think diffe- } \\
\text { rently from me. }\end{array}$ & 2.00 & 1.004 & 0.606 & 0.413 & 0.791 \\
\hline 39 & $\begin{array}{l}\text { Having a different social class from } \\
\text { my colleagues. }\end{array}$ & 1.89 & 0.999 & 0.622 & 0.411 & 0.789 \\
\hline 41 & Having to live alone. & 1.90 & 1.089 & 0.624 & 0.398 & 0.788 \\
\hline
\end{tabular}

Note. $D P=$ standard deviation; $r=$ correlation; $r^{2}=$ coefficient of determination; $\alpha=$ Cronbach's alpha.

The correlation matrix between the four factors and the overall scale indicate positive and significant correlations (Table 3), which allows stating that the increase or decrease of the indexes of a variable corresponds to the increase or decrease of the variable it correlates with. It is evident that, among the subscales, the lowest correlational value occurs between factor 4 and factor $2(r=0.474)$, with an explained variance of $22.46 \%$ and the greatest correlation between factors 3 and factor $1(r=0.689)$, with variability of $47.47 \%$. Among the different subscales and the overall factor, the correlations are higher, which explains the score above $61.0 \%$. 
Table 3

Pearson's Correlation matrix between the factors of the Higher Education Dropout Scale

\begin{tabular}{lllll}
\hline Factors & F1 & F2 & F3 & F4 \\
\hline Life Management Dimension - F2 & $0.670^{* * *}$ & -- & & \\
\hline Professional Dimention - F3 & $0.689^{* * *}$ & $0.652^{* * *}$ & - & \\
\hline Relational Dimension - F4 & $0.648^{* * *}$ & $0.474^{* * *}$ & $0.590^{* * *}$ & - \\
\hline Total Factor & $0.893^{* * *}$ & $0.836^{* * *}$ & $0.869^{* * *}$ & $0.783^{* * *}$ \\
\hline
\end{tabular}

Note. F1 = Organizational Dimension; F2 = Life management Dimension; F3 = Professional Dimension; F4 = Relational Dimension.

\section{Discussion}

The main objective of this study was to adapt and validate the Reasons for Higher Education Dropout Scale for its use with the Portuguese population. There was no translation since the original instrument was written in Brazilian Portuguese. However, some semantics corrections were necessary, especially regarding sentence construction and replacement of some terms not used in European Portuguese.

The results were obtained from a sample consisting of 891 higher education students, mostly female (68.2\%), with a minimum age of 17 and a maximum of 40 ( $M=19.68$ years \pm 2.34 years $)$, for the total sample.

Literature states that the validity of an instrument cannot be regarded as an intrinsic characteristic but rather a characteristic of the instrument itself when applied to a sample. It can, therefore, be concluded that the characteristics of the population under study can directly influence the structure of a scale. The exploratory analysis of the Reasons for Higher Education Dropout Scale indicated the existence of a 4-factor construct, being that the retained four factors explained $49.02 \%$ of the total variance. Nevertheless, the instrument's original structure was subdivided into seven factors. No other studies were found on the validation of the instrument, which limits the comparability of results.

The reliability and validity studies through exploratory and confirmatory factorial analysis allow stating that the Reasons for Higher Education Dropout Scale constitutes a valid and reliable instrument, adapted to the study of the school dropout intention of Portuguese higher education students.

It is considered that the reliability and validity analysis of the Reasons for Higher Education Dropout Scale is a crucial aspect. This is because, having the instrument been used to operationalize the central variable and, depending on the study, the value of its results as well as its conclusions, they depend on their conceptual and psychometric qualities.

The Reasons for Higher Education Dropout Scale (M-ES; Ambiel, 2015) was then composed of 30 items related to the reasons that influence the decision of higher education dropout, instead of the 53 items of the original scale. In favor of the conceptual validity of the construct, it can be noted that the factorial structure complies with theoretical foundations that support the dropout intention. Yet, there are items which, based on content analysis, would be put in the same category, but are integrated into different factors through the factorial analysis. Some of the items were eliminated because they showed saturations below the reference values during the internal consistency analysis and exploratory factor analysis. Others were eliminated during the confirmatory factor analysis, because they proved to be redundant, not clearly defining the aspects under evaluation.

Another argument in favor of the validity of the M-ES is the fact that the scale presents high and statistically significant correlations between the dimensions and are, therefore, not redundant, meaning that they evaluate different aspects of the same construct.

The exploratory and confirmatory factor analysis demonstrates the validity of the scale's structure in four dimensions: Organizational (F1), with eight items; Life management (F2), with seven items; Professional (F3), with eight items; and Relational (F4), with seven items.

The scale's original proposal (Ambiel, 2015) recommended evaluating the dropout intention 
based on the overall score of each factor, obtained by the sum of the score attributed to each item of this factor. This study suggests that the final score must be based on the second hierarchical factor (Marôco, 2014), which considers the loading of each item and each factor for the sample. This procedure seems, to the authors of this study, to be more adequate because, as the abovementioned author states, according to the classical theory of items, an instrument by itself cannot be considered valid.

\section{Conclusion}

Recently, there has been an increasing interest in assessing the possible reasons for active students to drop out of courses they enrolled in before completing them. For this purpose, it was necessary to create and/or adapt specific instruments for this population.

It can be concluded that this instrument is very reliable and has good indexes of internal consistency. Due to the time limitation, the study of temporal stability was not conducted, but later studies will carry it out.

Similarly, it was not possible to perform studies concerning convergent validity due to the lack of previous studies with similar instruments. This limits this study, since it makes it difficult to compare it with other instruments that might have been built based on the same theoretical constructs. It should also be noted, as a limitation of the study, that the scale has been applied to higher education students from a polytechnic institute located in the interior of the country. Considering the different contexts in the country and their influence, future research on the application of the scale may highlight their functioning in students from other educational institutions. However, the conclusion is that the psychometric adequacy of the Reasons for Higher Education Dropout Scale for the Portuguese population indicates that it could be used in future trials aimed at raising awareness to the school dropout intention and allowing the implementation of measures to fight it.

\section{Acknowledgments}

This work is funded nationally by the FCT Foundation for Science and Technology, I.P., within the context of the project UID / Multi /
04016/2016. Furthermore, the authors would like to thank the Polytechnic Institute of Viseu, the Viseu Higher School of Health, and the CI\&DETS for their support.

\section{References}

Ambiel, R. A. (2015). Construçáo da escala de motivos para evasão do ensino superior. Avaliação Psicológica, 14(1), 41-52. doi:10.15689/ap.2015.1401.05

Albuquerque, T. (2008). Do abandono à permanência num curso de ensino superior. Sísifo: Revista de Ciências da Educação, 7, 19-28. Retrieved from_https://www.researchgate.net/publication/28240665_Do_abandono_a_permanencia_num_curso_de_ensino_superior

Baptista, J. O. (2015). Indicadores de transferência e de abandono no ensino superior português. Retrieved from http://www.dgeec.mec.pt/np4/\%7B \$clientServletPath\%7D/?newsId=499\&fileName=2_Apresentacao_DGEEC.pdf

Costa, A. F., \& Lopes, J. T. (Coord.). (2008). Os estudantes e os seus trajetos no ensino superior: Sucesso e insucesso, fatores e processos, promoção de boas práticas: Relatório final. Retrieved from http://etes.cies.iscte.pt/Ficheiros/ relatorio_ETES_completo.pdf

Despacho n. ${ }^{\circ}$ 6659/99 de 5 de abril. (1999). Diário da República no 79, II Série. Ministério da Educação e Ciência. Lisboa, Portugal.

Direção-Geral do Ensino Superior (2014). Linhas de orientação estratégica para o ensino superior. Retrieved from https://www.dges.gov.pt/sites/default/files/mec_linhas_ estrategicas_enssup.pdf

Ferreira, F., \& Fernandes, P. (2015). Fatores que influenciam o abandono no ensino superior e iniciativas para a sua prevenção o olhar de estudantes. Educação, Sociedade \& Culturas, 45, 177-197. Retrieved from https://www. fpce.up.pt/ciie/sites/default/files/ESC45Ferreira.pdf

Marôco, J. P. (2014). Análise de equaçôes estruturais: Fundamentos teóricos, software \& aplicaçōes ( $2^{\mathrm{a}} \mathrm{ed}$.). Pêro Pinheiro, Portugal: ReportNumber.

Pestana, M. H., \& Gageiro, J. N. (2014). Descobrindo regressão: Com a complementaridade do SPSS. Lisboa, Portugal: Silabo.

Resolução da Assembleia da República n. ${ }^{\circ}$ 60/2013 de 18 de abril. (2013). Diário da República no 76, I Série. Assembleia da República. Lisboa, Portugal.

Sequeira, P. M. (2013). Contribuição da inteligência emocional para o sucesso escolar no contexto da formação em medicina (Master's Dissertation). Universidade da Beira Interior, Covilhã, Portugal. Retrieved from http://ubibliorum. ubi.pt/bitstream/10400.6/2686/1/Disserta\%C3\%A7\%C3\%A3o_IE_SE_Patricia\%20Barata.pdf 
